\title{
A interação tectônica embasamento/cobertura em aulacógenos invertidos: um exemplo da Chapada Diamantina Ocidental
}

\author{
Simone Cerqueira Pereira Cruz, ${ }^{1}$, Vilson Marques Dias ${ }^{2}$ \& Fernando Flecha Alkmim ${ }^{1}$
}

\begin{abstract}
Resumo Um cinturão de dobramentos e cavalgamentos com embasamento envolvido está exposto ao longo da borda ocidental da Chapada Diamantina, um platô recoberto por unidades proterozóicas no interior da porção setentrional do Cráton do São Francisco. Esse cinturão, com trend NNW e vergência ENE, envolve uma parte substancial da porção leste do Aulacógeno do Paramirim, que corresponde a um rifte intracontinental que experimentou uma longa história de desenvolvimento iniciada em 1,75 Ga com a sedimentação do Supergrupo Espinhaço. Após a deposição da segunda maior unidade de preenchimento, o Supergrupo São Francisco, de idade neoproterozóica (Tonian-Cryogeninan), o rifte do Paramirim experimentou uma vigorosa inversão positiva que gerou um sistema de falhas e dobras com trend NNW. Com o intuito de contribuir com o entendimento da tectônica de inversão envolvendo o embasamento, foi realizada a análise estrutural baseada em dados de campo ao longo da borda oeste da Chapada Diamantina. Os resultados indicam que o processo de inversão ocorreu em quatro fases coaxiais de deformação progressiva. Sob um campo de encurtamento geral orientado segundo WSW-ENE, a primeira fase de deformação $\left(\mathrm{D}_{\text {pdesc }}\right)$ nucleou um sistema em que a cobertura se descolada do embasamento nucleando estruturas vergentes para ESE, incluindo descolamentos intra-estratais, leques imbricados, duplexes confinados a estratos e uma variedade de estruturas de pequena escala. Reativando estruturas pré-existentes, a fase deformacional subseqüente $\left(\mathrm{D}_{\mathrm{p} 1} \mathrm{D}_{\mathrm{p} 2}\right)$ foi responsável pela geração de falhas reversas envolvendo o embasamento, zonas de cisalhamento reversas a oblíquas e grandes dobras com trend NNW que domina o cenário estrutural da borda oriental da Chapada Diamantina. Durante a fase $\mathrm{D}_{\mathrm{p} 3} \mathrm{um}$ trem de dobras orientadas segundo NNW, vergente para WSW e associada com uma proeminente clivagem de crenulação desenvolveu-se sobre as estruturas previamente deformadas em zonas de alta deformação da borda oriental da Chapada Diamantina.
\end{abstract}

Palavras-chave: aulacógeno, Chapada Diamantina, embasamento, Cráton do São Francisco.

Abstract Interaction Between Basement and Sedimentary Cover Related to Inverted Aulacogens: the Western Chapada Diamantina. A basement-involved fold-trust belt is exposed along the western border of the Chapada Diamantina, a high plateau underlain by proterozoic units in the interior of the northern São Francisco craton. This NNW-trending and ENE-verging fold fold-thrust belt encompasses a substantial part of the eastern portion of the Paramirim aulacogen, which corresponds to a intracratonic rift basin that experienced a long history of development starting at ca. $1.75 \mathrm{Ga}$ with sedimentation of Espinhaço Supergroup. After the deposition of its second major fill unit, the Neoproterozoic (Tonian-Cryogeninan) São Francisco Supergroup, the Paramirim rift experienced a vigorous positive inversion that generated the system of NNW-trending faults and folds. Aiming to contribute to better understanding of basement-involved inversion tectonics, we carried out a field based structural analysis along the western Chapada Diamantina. Our results indicated that the inversion process took place according to four coaxial phases of progressive deformation. Under an overall WNWESE oriented shortening, the first phase of deformation $\left(\mathrm{D}_{\text {pdess }}\right)$ nucleated a thin-skinned system of ESE-verging structures, including layer controlled detachments, blind imbricate fans, strata-confined duplexes and a variety of small-scale structures. Reactivating pre-exiting structures, the subsequent deformation phases $\left(\mathrm{D}_{\mathrm{p} 1 / \mathrm{p} 2}\right)$ were responsible for the generation of basement-involved reverse faults, reverse to oblique-slip ductile shear zones and large-scale NNW-trending folds that dominate the structural picture of the western Chapada Diamantina. During the $\mathrm{D}_{\mathrm{p} 3}$-phase trains of NNW-oriented and WSW-verging folds associated with a prominent crenulation cleavage overprint the previously mentioned structures in the high strain zones of the western border of the Chapada Diamantina.

Keywords: aulacogen, Chapada Diamantina, basement, São Francisco craton.

INTRODUÇÃO A interação tectônica entre o substrato de rochas cristalinas e a cobertura sedimentar em sistemas invertidos e cinturões de dobramentos e cavalgamentos permite o desenvolvimento de estru-

1 - Depart. Geologia, Escola de Minas, Universidade Federal de Ouro Preto, Morro do Cruzeiro, Ouro Preto (MG), Brasil. E-mails: simoneufbag@mail.com, alkmim@degeo.ufop.br

2 - Instituto de Geociências, Universidade Federal da Bahia, Federação, Salvador (BA), Brasil. 
turas deformacionais cuja geometria é função das características intrínsecas das unidades envolvidas e da inter-relação entre a trama do substrato e da cobertura sedimentar. Alguns trabalhos descreveram a existência de interações desse tipo, por exemplo, O’Dea \& Lister (1995), McDowel (1997), Alkmim \& Danderfer Fo (1995) e Cruz (2000). Entretanto, algumas questões relacionadas a esse tema ainda permanecem sem resposta definitiva, tais como: $i$ ) Existe uma forma padrão de acomodação da deformação no embasamento e na cobertura? ii) Qual a relação temporal entre as estruturas do embasamento e da cobertura? iii) A partir da geometria das estruturas do substrato pode-se prever a geometria e orientação das estruturas na cobertura e vice-versa? iv) É possível se estabelecer um modelo cinemático para essa interação que seja reproduzível em todas as escalas?

Na Chapada Diamantina (Fig. 1) acha-se exposto um cinturão de cavalgamentos e dobramentos que tem como estruturas dominantes falhas reversas e de empurrão associadas às megadobras orientadas na direção NNW/SSE e vergentes para leste (Fig. 2). Esse cinturão é um dos registros da inversão do Aulacógeno do Paramirim durante o Neoproterozóico (Danderfer Fo 1990, 2000, Cruz \& Alkmim 2006).

O Aulacógeno do Paramirim (Pedrosa-Soares et al. 2001), que corresponde a uma expansão do conceito de Aulacógeno do Espinhaço de Moutinho da Costa \& Inda (1982) para englobar todas as feições e unidades expostas nas regiões da Serra do Espinhaço setentrional e da Chapada Diamantina, é um rifte ensiálico e quase integralmente invertido de orientação geral NNW/SSE, desenvolvido na porção norte do Cráton São Francisco durante o Paleo/Meso/Neoproterozóico. Possui como unidades de preenchimento os supergrupos Espinhaço e São Francisco.

A porção oeste do aulacógeno congrega os setores de máxima e mínima inversão os quais, juntos, definem uma faixa com largura que varia entre $65 \mathrm{~km}$, a norte, e $170 \mathrm{~km}$, a sul e orientação NNW-SSE. Tratase do Corredor do Paramirim (Alkmim et al. 1993) que abarca as regiões da serra do Espinhaço Setentrional, parte dos vales Paramirim, São Francisco e Gavião, como também a Chapada Diamantina Ocidental. Ao

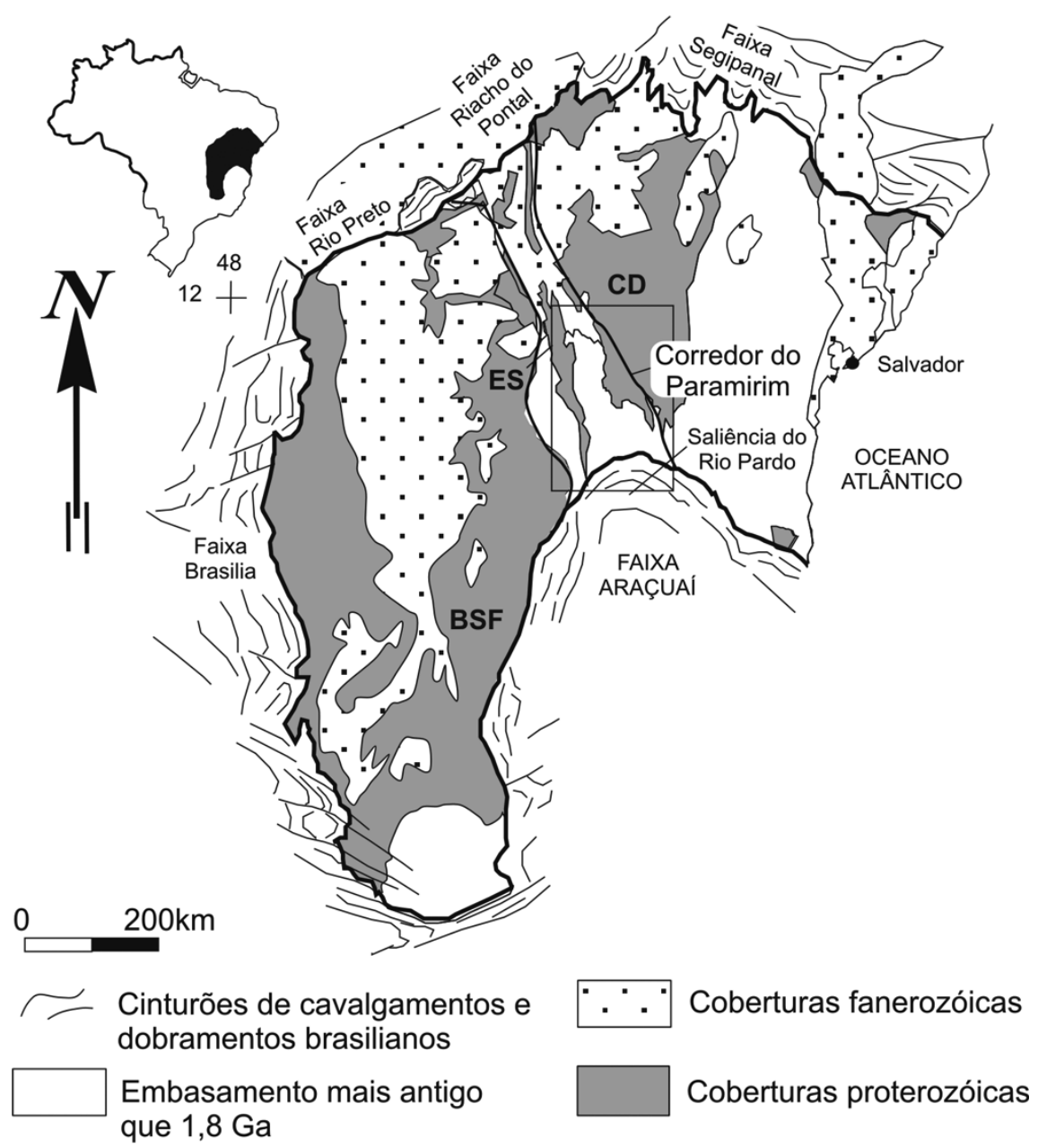

CD-Chapada Diamantina, ES- Espinhaço Setentrional, BSF- Bacia do São Francisco.

Figura 1 - O Cráton do São Francisco, o Aulacógeno do Paramirim e a Faixa Araçuaí. O quadro indica a localização da Figura 2. 




Figura 2 - Localização da área estudada no Corredor do Paramirim. O quadro representa a localização da Figura 3. Mapa construído a partir de Schobbenhaus et al. (1981) e Barbosa \& Dominguez (1996). Legenda: BG: Bloco Gavião, BJ: Bloco Jequié. ZCBC: Zona de cisalhamento Brumado-Caetité, ES: Espinhaço Setentrional, CD: Chapada Diamantina, FRP: Faixa Rio Preto, SRP: Saliência do Rio Pardo (Faixa Araçuai), SI: Sinclinal de Ituaçu, AAJ: Anticlinal de AbaíraJussiape.

longo da porção meridional do Corredor do Paramirim a deformação cresce de norte para sul. Nessa porção do corredor, no Espinhaço Setentrional a deformação cresce de oeste para leste (Moutinho da Costa \& Inda 1982). Na Chapada Diamantina, as maiores magnitudes da deformação são encontradas na sua porção sudoeste, região em que o embasamento está envolvido na deformação da cobertura, e a deformação cresce de leste para oeste (Danderfer Fo 1990, Danderfer Fo et al. 1993 , Cruz et al. 1998, Danderfer Fo 2000, Bento 2001, Cruz
\& Alkmim 2006).

No presente trabalho, descreve-se e interpretase o acervo de estruturas deformacionais que, ao longo da borda ocidental da Chapada Diamantina, resultam da inversão do Aulacógeno do Paramirim, com vistas à elucidação da forma pela qual interagem as rochas do substrato cristalino e as unidades sedimentares da cobertura desse setor do Corredor do Paramirim. Como substrato do Aulacógeno designa-se aqui o conjunto de rochas formado pelo embasamento do cráton, isto é, 


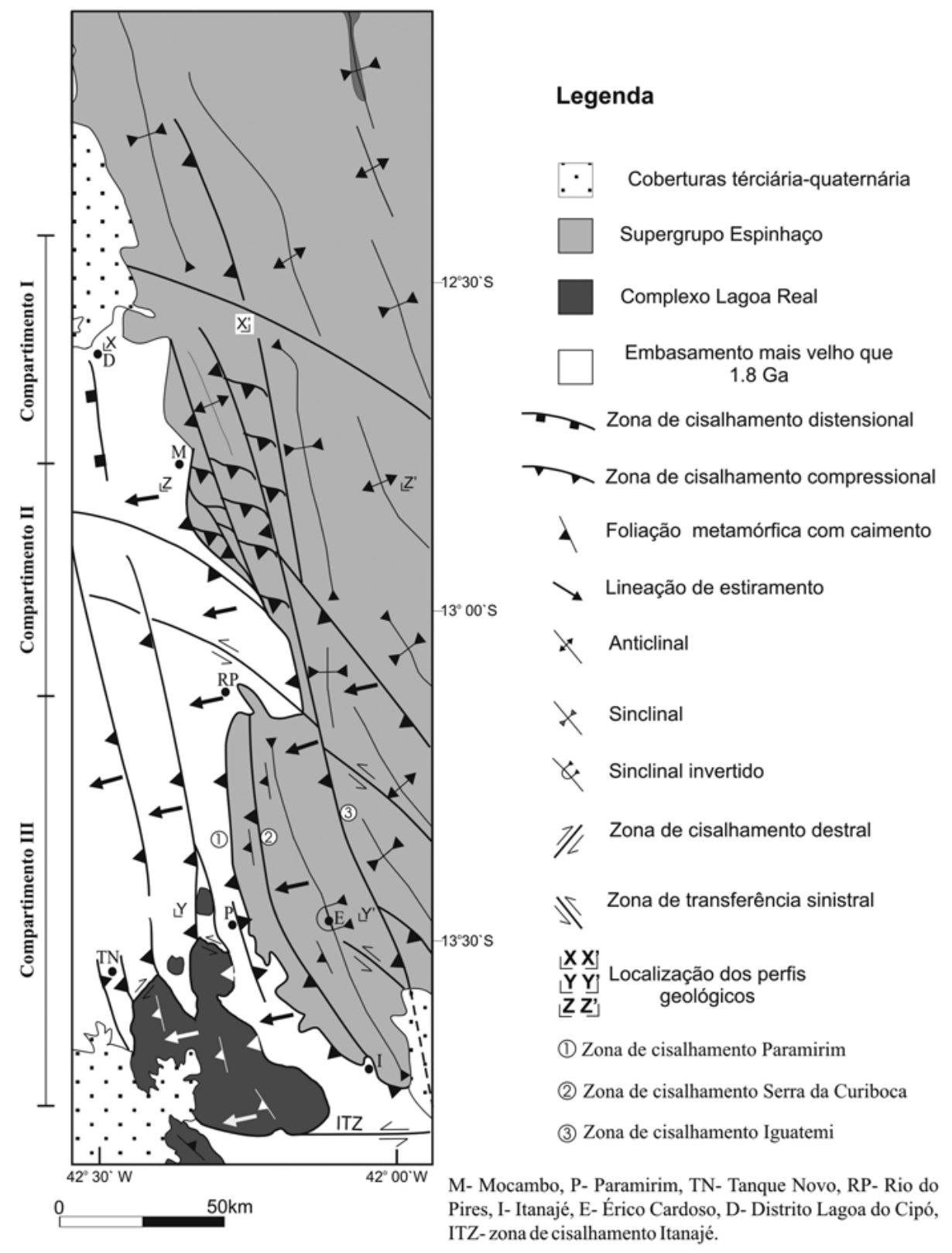

Figura 3 - Mapa Geológico simplificado da Borda Oeste da Chapada Diamantina contendo as principais unidades e traços estruturais. A sua localização encontra-se na Figura 2. Na Figura estão apresentados os perfis estudados em campo $\left(X-X^{\prime}, Y-Y^{\prime}, Z-Z^{\prime}\right)$.

unidades mais antigas que $1,8 \mathrm{Ga}$, e por plutônicas de $1,75 \mathrm{Ga}$. O substrato assim designado constitui o embasamento reológico do aulacógeno, cujo comportamento nos processos de deformação dá-se de maneira característica e distinta da cobertura sedimentar.

Para a realização deste trabalho foi selecionada uma faixa com $150 \mathrm{~km}$ de extensão e $60 \mathrm{~km}$ de largura ao longo da borda ocidental da Chapada Diamantina, compreendida entre o distrito de Lagoa do Cipó, a norte da localidade de Mocambo e a cidade de Itanajé. Nessa faixa, foram realizadas diversas seções geológicas $\mathrm{E}-\mathrm{W}$, estando três delas representadas na figura 3.

CONTEXTO REGIONAL O Cráton do São Francisco corresponde a um dos segmentos crustais que foram preservados da deformação e metamorfismo durante a aglutinação do Gondwana Ocidental, no evento Brasiliano. O embasamento da sua porção norte é composto por um conjunto de gnaisses e migmatitos de composição TTG, de idades arqueana e paleoproterozóica, e por seqüências metavulcanossedimentares, de idade arqueana (Brito-Neves et al. 1980, Cordani et al. 1985, Bastos-Leal 1998). Intrusivos nessas rochas, granitóides paleoproterozóicos ocorrem amplamente distribuídos na porção central do Cráton do São Francisco (Maruèjol et al. 1987, Cordani et al. 1992). Esses granitóides encontram-se deformados em graus variáveis e foram agrupados no Complexo Lagoa Real (Costa et al. 1985). O substrato encontra-se recoberto por unidades sedimentares de idades paleo/meso e neoproterozóica, 


\section{CHAPADA DIAMANTINA}

a) Barbosa \& Dominguez (1996)
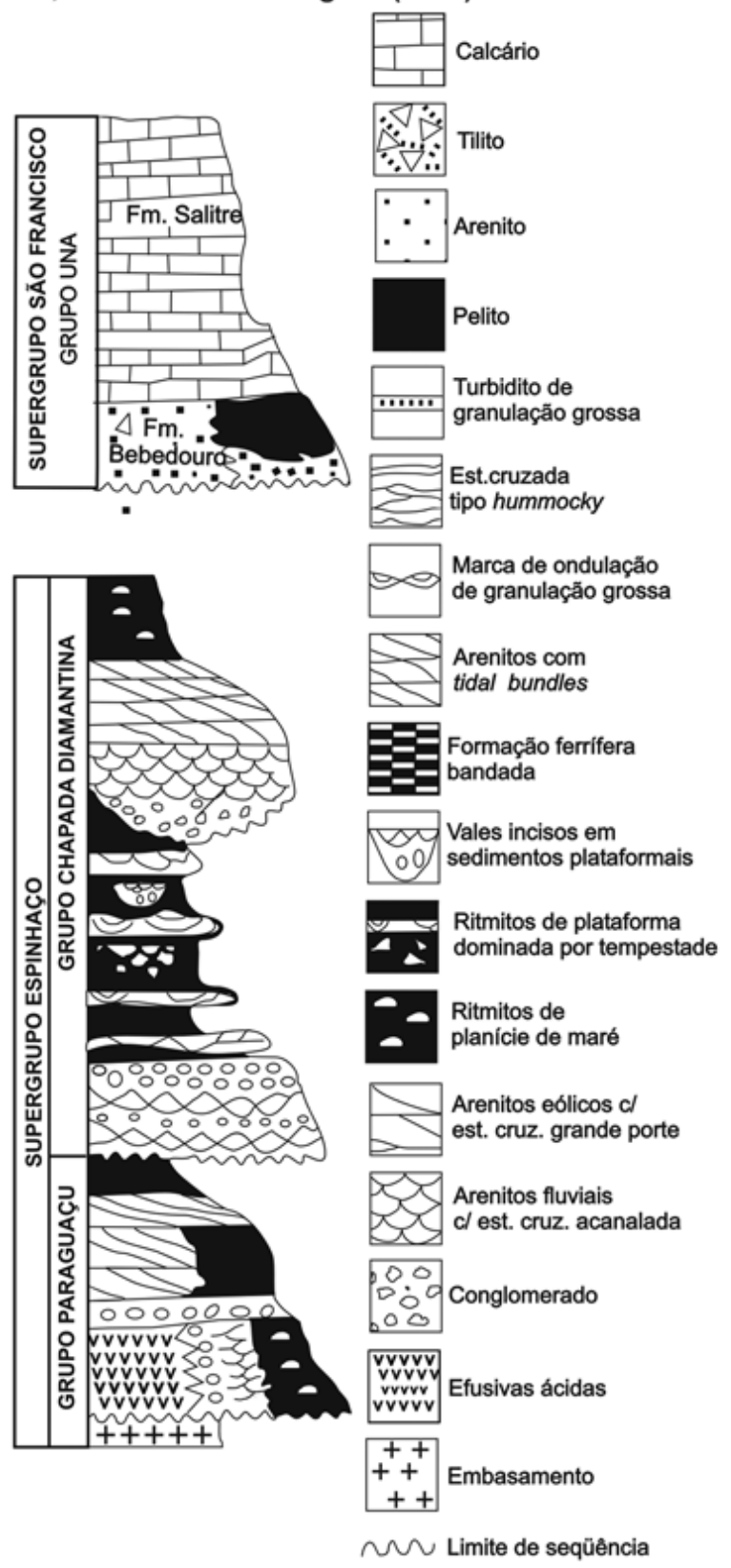

b) Danderfer $\mathrm{F}^{\circ}(\mathbf{2 0 0 0 )}$
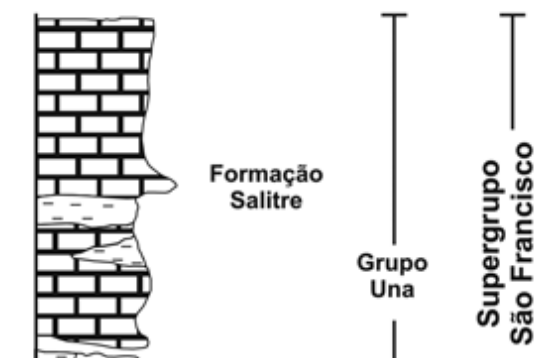

品
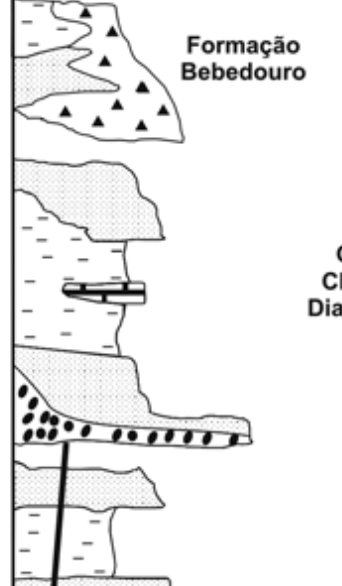

Chapada

Chapada


Grupo

Paraguaçu
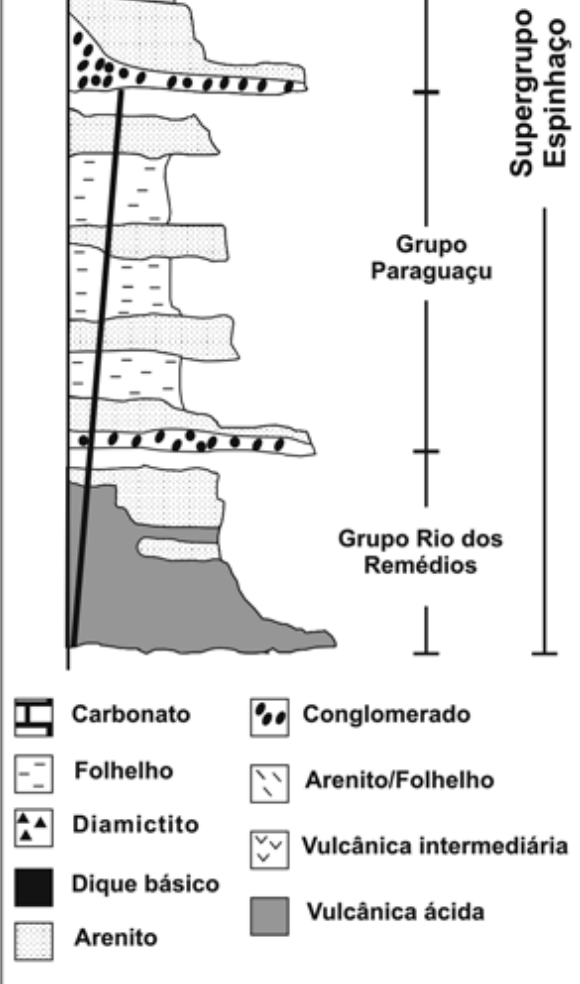

Figura 4 - Propostas de empilhamento estratigráfico para a Chapada Diamantina segundo Barbosa \& Dominguez (1996) (a) e Danderfer Fo (2000) (b).

agrupadas nos supergrupos Espinhaço e São Francisco.

O Supergrupo Espinhaço engloba sedimentos de natureza predominantemente terrígena, com contribuições vulcânicas ácidas a intermediárias em sua base. A sua deposição reflete a instalação de sucessivos eventos de rifteamento e de subsidência flexural entre o Paleo e o Mesoproterozóico (Danderfer Fo 1990, 2000). Babinski et al. (1994) obtiveram uma idade U/Pb de 1,748 \pm 1 Ma em zircões de rochas vulcânicas da base do Supergrupos Espinhaço, na Chapada Diamantina, que foi atribuída à deposição dessas rochas. Em ilitas da Formação Caboclo, Macedo \& Bonhomme (1984) encontraram idades $\mathrm{Rb}-\mathrm{Sr}$ em torno de $960 \mathrm{Ma}$, atribuídas a diagênese dessa unidade.

O Supergrupo São Francisco compreende sedimentos glácio-marinhos recobertos por um pacote de carbonatos com intercalações de siliciclásticos (Guimarães 1996) que correspondem, respectivamente, às formações Bebedouro e Salitre. Baseado em estudos isotópicos $(\mathrm{Rb} / \mathrm{Sr})$ em carbonatos, Misi \& Veizer (1996) e Toulkeridis et al. (1999) sugerem idades de deposição das rochas da Formação Salitre entre 750 e 850 Ma.

Diversas propostas foram levantadas para explicar o empilhamento estratigráfico dos supergrupos 
Espinhaço e São Francisco na Chapada Diamantina, dentre elas destacando-se as de Barbosa \& Dominguez (1996) e Danderfer Fo (2000) (Fig. 4).

O Aulacógeno do Paramirim experimentou um processo de inversão que deu origem ao sistema de falhas e dobras da Chapada Diamantina e também ao chamado Corredor do Paramirim (Alkmim et al. 1993 , 1996) (Fig. 1). O Corredor do Paramirim compreende toda a região entre a Chapada Diamantina Ocidental e a serra do Espinhaço Setentrional, sendo a zona de máxima inversão do aulacógeno.

O ARCABOUCO ESTRUTURAL DA BORDA OCIDENTAL DA CHAPADA DIAMANTINA A análise estrutural realizada na borda ocidental da Chapada Diamantina permitiu a caracterização de duas famílias de estruturas. A primeira, de natureza distensional, $\left(\mathrm{D}_{\mathrm{n}}\right)$, ocorre predominantemente no substrato, e está marcada por falhas normais, de alto ângulo e orientação preferencial segundo NNW/SSE. Essas estruturas estão bem preservadas na região acima do paralelo $12^{\circ} 45^{\prime} \mathrm{S}$. Elas estão relacionadas com a instalação do Aulacógeno do Paramirim.

A segunda família de estruturas $\left(D_{p}\right)$ é compressional e nucleou-se durante a inversão frontal do aulacógeno em quatro etapas distintas, descritas a seguir.

A Etapa $D_{\text {pdesc }}$ marca a fase dos descolamentos entre as unidades de cobertura e o embasamento, com o desenvolvimento de estruturas segundo NNW/SSE e vergentes para ENE. Na cobertura, as estruturas mais antigas são zonas de cisalhamento inter e intra-estratais que se desenvolvem aproveitando o acamamento primário. Essas zonas ocorrem alojadas, preferencialmente, nos níveis pelíticos e de metavulcânicas e na interface entre unidades de composição distintas. As megadobras da Chapada Diamantina envolvem tanto acamamento primário quanto as zonas inter e intra-estratais e foram, portanto, nucleadas após a fase dos descolamentos. Deslizamentos intraestratais sin-dobramentos são observados, com nucleação, nos limbos, de estruturas como tension gashes e estruturas $\mathrm{S} / \mathrm{C}$ vergentes para a charneira.

As Etapas $D_{p 1} / D_{p 2}$ correspondem à fase de envolvimento do embasamento na deformação da cobertura. A distinção entre essas duas etapas de deformação só é possível nas rochas do embasamento e do Complexo Lagoa Real. A etapa $\mathrm{D}_{\mathrm{p} 1}$ foi responsável pela gnaissificação dos granitóides do Complexo Lagoa Real. $\mathrm{Na}$ etapa seguinte, $\mathrm{D}_{\mathrm{p} 2}$, zonas de cisalhamento rúptildúcteis foram nucleadas e essas estruturas instalaramse aproveitando antigas descontinuidades. Durante essa fase foram gerados níveis de filonitos. Na cobertura o envolvimento do embasamento é marcado pela nucleação de zonas de cisalhamento rúptil-dúcteis ancoradas no embasamento com orientação NNW/SSE e vergentes para ENE. Na borda oeste da Chapada Diamantina podem ser identificadas 3 zonas de cisalhamento principais, denominadas zona de cisalhamento Paramirim, zona de cisalhamento Serra da Curiboca e zona de cisalhamento Iguatemi (Fig. 3). Como será demonstrado a seguir, a sul do paralelo $13^{\circ} 00^{\prime} \mathrm{S}$, tais zonas promovem inversões estratigráficas e colocam o embasamento sobre e intercalado com as unidades de cobertura.

A Etapa $D_{p 3}$ é caracterizada pelo desenvolvimento de dobras abertas associadas a uma proeminente clivagem de crenulação que rotaciona todas as estruturas previamente nucleadas. Seus eixos orientam-se na direção NNW/SSE e vergem para WSW.

De acordo com a distribuição dos elementos estruturais relacionados com as duas famílias de estruturas reconhecidas, a área estudada foi subdividida em três compartimentos distintos. Em todos eles, falhas transferentes sinistrais de orientações WNW-ESSE foram encontradas (Fig. 3).

\section{Compartimento I: Região compreendida entre Quei-} mada Nova e Mocambo No Compartimento I (Fig. 3), a trama deformacional pré-inversão está bem preservada. O substrato compreende, predominantemente, gnaisses, com estruturação bastante complexa e atribuída ao Arqueano (Jardim-de-Sá et al. 1976, Brito-Neves et al. 1980, Cordani et al. 1992). Truncando essas estruturas, tem-se uma série de zonas e fraturas de cisalhamento de médio ângulo, com orientação preferencial NNW/SSE, lineação de alta obliqüidade (Figs. 5a, b) e movimentação normal a normal sinistral, as quais representam as estruturas originais do aulacógeno (Dn).

Nesse compartimento, a seqüência do Supergrupo Espinhaço se inicia com os metavulcanitos da Formação Rio dos Remédios que se encontram sotopostos aos metaconglomerados e metarenitos da Formação Ouricuri do Ouro. Na interface embasamento/cobertura observa-se uma zona de cisalhamento milonítica de baixo ângulo com cerca de $2 \mathrm{~m}$ de espessura. Essa superfície, cuja atitude modal é 250/10 (Fig. 5c), apresenta-se dobrada e sobre ela, desenvolve-se uma lineação de estiramento posicionada em WSW-ENE (Fig. 5d). Essa zona de cisalhamento marca o descolamento entre o embasamento e a cobertura durante as fases iniciais da deformação compressiva principal $\left(\mathrm{D}_{\text {pdesc }}\right)$. Acima dela, as rochas dos grupos Rio dos Remédios e Paraguaçu (Supergrupo Espinhaço), de uma maneira geral, conservam as suas estruturas primárias. Veios subverticais com proporções variáveis de quartzo, microclina, fluorita e magnetita podem ser encontrados cortando o acamamento sedimentar.

As estruturas deformacionais dominantes nas rochas da cobertura do Compartimento I são megadobras regionais (Fig. 6a), relativas ao estágio $\mathrm{D}_{\text {pdesc }}$, cuja orientação preferencial é NNW/SSE (Fig. 5e). Apresentam-se com geometria em kink (Fig. 7), em caixa ou também com charneiras arredondadas. Raramente desenvolvem foliação de plano axial, mesmo nas unidades pelíticas. Quando presentes, essas superfícies posicionam-se em 253/72 (Fig. 5f).

No interior das grandes dobras podem ser encontradas zonas de cisalhamento intra e interestratais relativas ao estágio $\mathrm{D}_{\text {pdesc }}$, que, ao cortarem as unidades metareníticas, dão origem a cataclasitos e ultracataclasitos. De uma maneira geral, essas zonas de cisalha- 



Foliação milonítica - $\mathrm{S}_{\text {pdesc }}$

Descolamento basal

Compartimento I

Máximo: 250/10
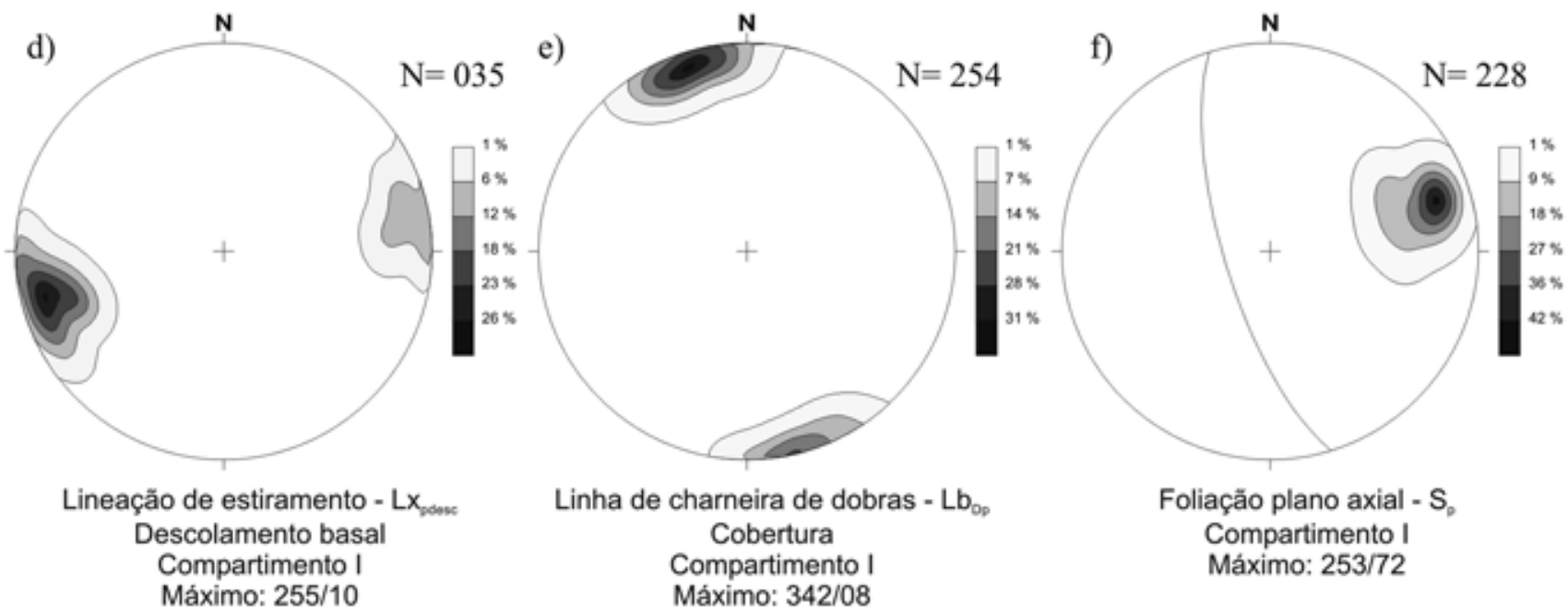

Figura 5 - Diagramas estereográficos sinópticos (hemisfério inferior) das estruturas deformacionais identificadas no Compartimento I.

mento não desenvolvem estrias de movimento.

Compartimento II: Região entre Mocambo e Rio do Pires O substrato desse compartimento é composto pelos gnaisses da infra-estrutura. Neles, a deformação foi acomodada por uma série de zonas de cisalhamento reversas, espaçadas (Fig. 6b), marcada por uma foliação milonítica penetrativa, sobre a qual se desenvolve uma lineação de estiramento. As orientações da foliação e lineação são, respectivamente, 242/63 e 243/63 (Figs. 8a, b). Tais zonas de cisalhamento, em função do seu ângulo de mergulho, devem ser produto da reativação de antigas falhas normais nucleadas durante a instalação do aulacógeno, uma vez que possuem atitudes semelhantes às falhas normais pré-inversão identificadas no compartimento I (Fig. 5a). Em seu interior, predominam filonitos, a quartzo, clorita e mica branca. O bandamento metamórfico é marcado pela alternância entre níveis ricos em quartzo e níveis ricos em filossi- licatos.

Nesse compartimento (Fig. 6b), o Supergrupo Espinhaço também se inicia com os vulcanitos da Formação Rio dos Remédios, aos quais se sobrepõem metaconglomerados e metarenitos fluviais da Formação Ouricuri do Ouro. De uma maneira geral, as unidades de cobertura continuam repousando sobre o substrato de rochas cristalinas e delas separadas pela superfície de descolamento. A monotonia é quebrada pela presença de zonas de cisalhamentos de alto ângulo que foram nucleadas durante os estágios $\mathrm{D}_{\mathrm{pl}} / \mathrm{D}_{\mathrm{p} 2}$ Tais estruturas possuem orientação, em geral, NNW/SSE e truncam a superfície de descolamento basal. Além disso, são responsáveis por cavalgar as rochas metassedimentares do Supergrupo Espinhaço sobre as rochas do substrato cristalino. Em planta, o arranjo geral das zonas de cisalhamento é anastomosado, em sigmóides, as quais indicam uma componente destral de deslocamento horizontal. 




Figura 6 - Perfis geológicos esquemáticos na Chapada Diamantina. A sua localização está indicada na Figura 2. Os perfis $A-A$ ', $B$-B' e $C$-C' contêm os compartimentos I, II e III, respectivamente (vide figura 3).



Figura 7 - Dobras com geometria em kink desenvolvidas em pelitos da Formação Caboclo (Supergrupo Espinhaço. Afloramento ao longo da BR-242 (Compartimento I). Foto em perfil.

Ao adentrarem as unidades do Supergrupo Espinhaço, as zonas de cisalhamento $\mathrm{D}_{\mathrm{p} 1} / \mathrm{D}_{\mathrm{p} 2}$ truncam o acamamento primário, as zonas de cisalhamento intra $\mathrm{e}$ interestratais pré-existentes e megadobras desenvolvidas na fase $\mathrm{D}_{\text {pdesc }}$. Nas unidades metareníticas, as zonas de cisalhamento possuem pouca expressão em afloramento, sendo responsáveis por basculamentos de camadas. Nesse caso, tais zonas se apresentam espaçadas e estreitas (máximo de 1 metro de largura). Na região de Mocambo, onde predominam as rochas metavulcanogênicas da Formação Rio dos Remédios e metaconglomeráticas, as zonas de cisalhamento $\mathrm{D}_{\mathrm{p} 1} \mathrm{D}_{\mathrm{p} 2}$ atingem larguras de até $20 \mathrm{~km}$. Nesse contexto, protomilonitos, milonitos, ultramilonitos, quartzo-filonitos e filonitos são amplamente desenvolvidos no seu interior. Predominam quartzo-mica branca filonitos e mica branca filonitos.

A foliação e a lineação de estiramento associadas com as zonas de cisalhamento $\mathrm{D}_{\mathrm{p} 1} \mathrm{D}_{\mathrm{p} 2}$ são bem desenvolvidas. A foliação dispõe-se, preferencialmente, segundo 241/67 (Fig. 8c). A lineação de estiramento é marcada pelos cristais de mica branca e por ribbons policristalinos de quartzo. Essa estrutura apresenta-se com alta obliqüidade e possui orientação modal 251/61 (Fig. 8d).

Fora das zonas de cisalhamento desse estágio deformacional, as unidades preservam as suas estruturas originais e a deformação é marcada pelo desenvolvimento de estruturas da fase de descolamento entre a cobertura e o embasamento. Nos metarenitos, as dobras são abertas, com charneiras arredondadas, dispostas na 

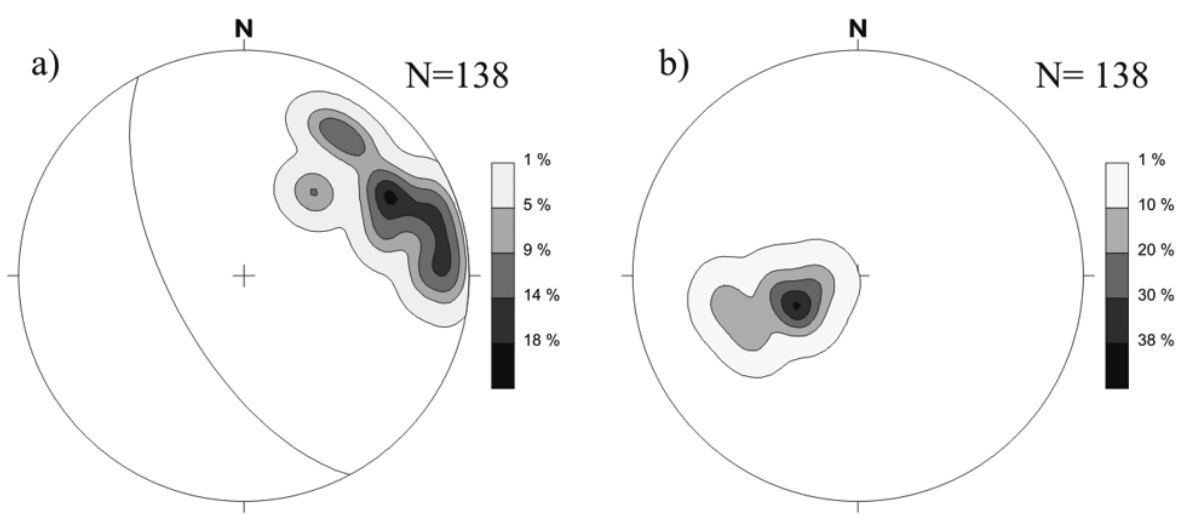

Foliação milonítica - $\mathrm{S}_{\mathrm{p}}$ Embasamento Zona de cisalhamento reversa Compartimento II Máximo: 242/63

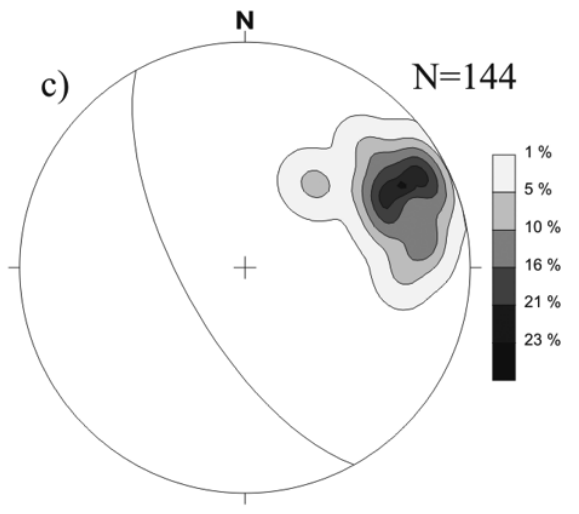

Foliação milonítica - $\mathrm{S}_{\mathrm{p}}$ Cobertura

Zona de cisalhamento reversa Compartimento II Máximo: 241/67

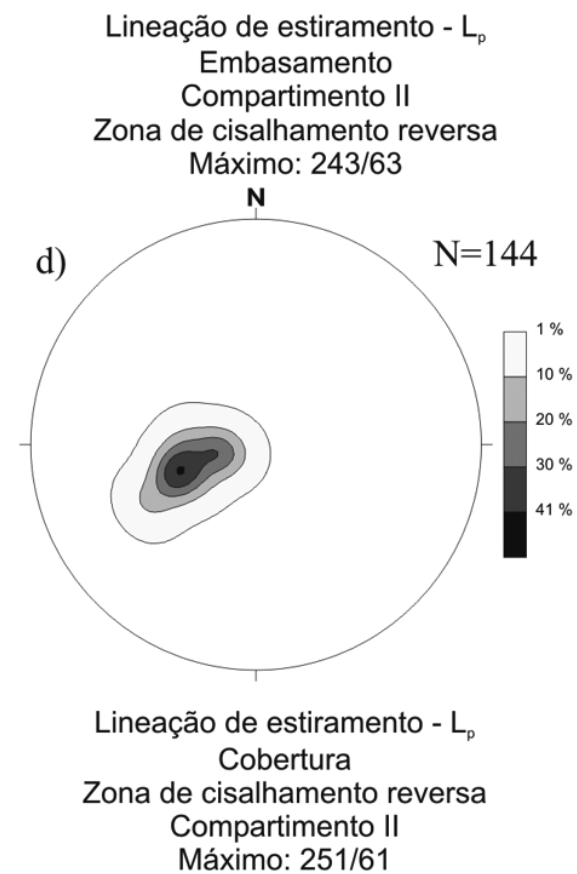

Figura 8 - Diagramas estereográficos sinópticos (hemisfério inferior) das estruturas deformacionais identificadas no Compartimento II.

direção 336/12. Nas rochas metapelíticas, as dobras são apertadas, assimétricas e vergentes para leste. A superfície axial orienta-se, preferencialmente, em 250/45.

Compartimento III: Região entre Rio do Pires e Itanajé A estrutura dominante do Compartimento III é a Sinclinal de Água Quente que apresenta seu limbo oeste invertido (Fig. 6c). Apresenta $70 \mathrm{~km}$ de comprimento e $20 \mathrm{~km}$ de largura e em seu limbo oeste, envolve o embasamento, o Complexo Lagoa Real e as rochas do Supergrupo Espinhaço. De acordo com a natureza das rochas envolvidas e com o registro estrutural encontrado, o Compartimento III foi subdividido em três domínios estruturais, ocidental, central e oriental (Fig. 9).

DOMÍNIO OCIDENTAL Compreende, em sua totalidade, a região de ocorrência do Complexo Lagoa Real. Nesse domínio formou-se um conjunto de zonas de cisalhamento reversas com direção geral NNW-SSE, responsáveis pela geração milonitos e ultramilonitos a partir de granitóides do Complexo Lagoa Real. Nesses tectonitos, o bandamento composicional sin-deformacional é bem desenvolvido, sendo marcado pela alternância de níveis ricos em fragmentos de feldspatos e grãos de quartzo recristalizados, níveis ricos em quartzo e níveis ricos em clorita e biotita verde, que nesse caso, compõe a foliação metamórfica. A foliação milonítica encontra-se heterogeneamente desenvolvida e, em geral, apresenta-se com a orientação 257/41 (Fig. 10a). A lineação de estiramento é bem desenvolvida, marcada por clorita e biotita verde e orienta-se, preferencialmente, segundo 255/40 (Fig. 10b).

O contato ente o domínio ocidental e o domínio central se faz por intermédio da zona de cisalhamento São Timóteo, que coloca os gnaisses Lagoa Real sobre as rochas do embasamento (Figs. 6c, 9).

DOMÍNIO CENTRAL Corresponde à região a oeste da Sinclinal de Água Quente (serras da Pedra Preta e Curiboca) dominada por cavalgamentos ancorados nos descolamentos intra-estratais e dobras (Figs. 6c e 9). Nela, a deformação envolveu o embasamento, as rochas metaconglomeráticas e metareníticas da Forma- 

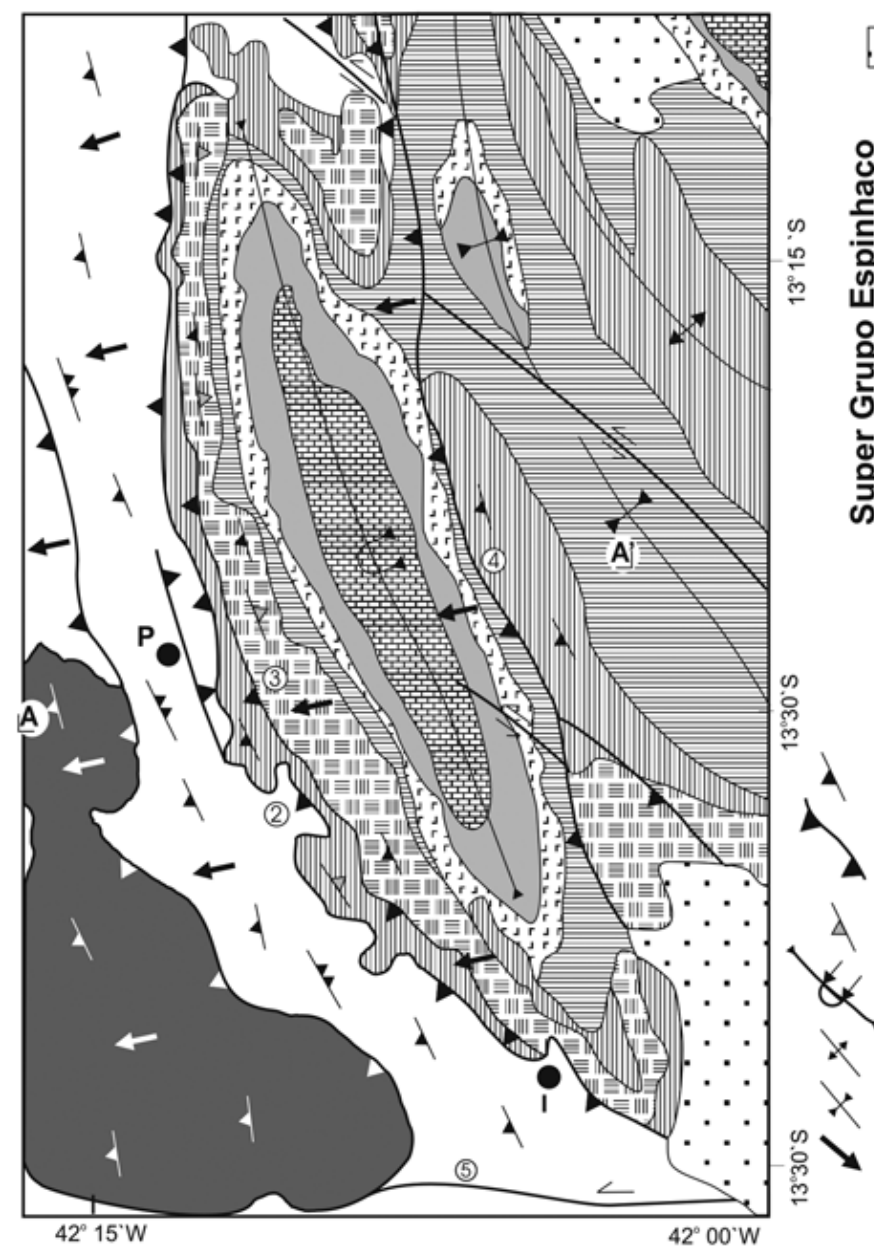

$\because$ Coberturas térciário-quaternárias

\section{Grupo Chapada Diamantina}



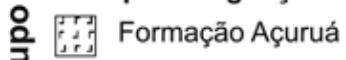

仓 擮 Formação Lagoa de Dentro

๗ํㅡㄹ

|l| Formação Ouricuri do Ouro

핌 Formação Rio dos Remédios

Complexo Lagoa Real

Embasamento mais velho
que $1.8 \mathrm{Ga}$

Foliação metamórfica $S_{p 1}$

Zona de cisalhamento

Reversa $\mathrm{S}_{\mathrm{p} 1} / \mathrm{S}_{\mathrm{p} 2}$

Foliação metamórfica $S_{p 3}$

Sinclinal com duplo caimento e limbo invertido

Anticlinal

Sinclinal

Lineação de estiramento - $L x_{p}$
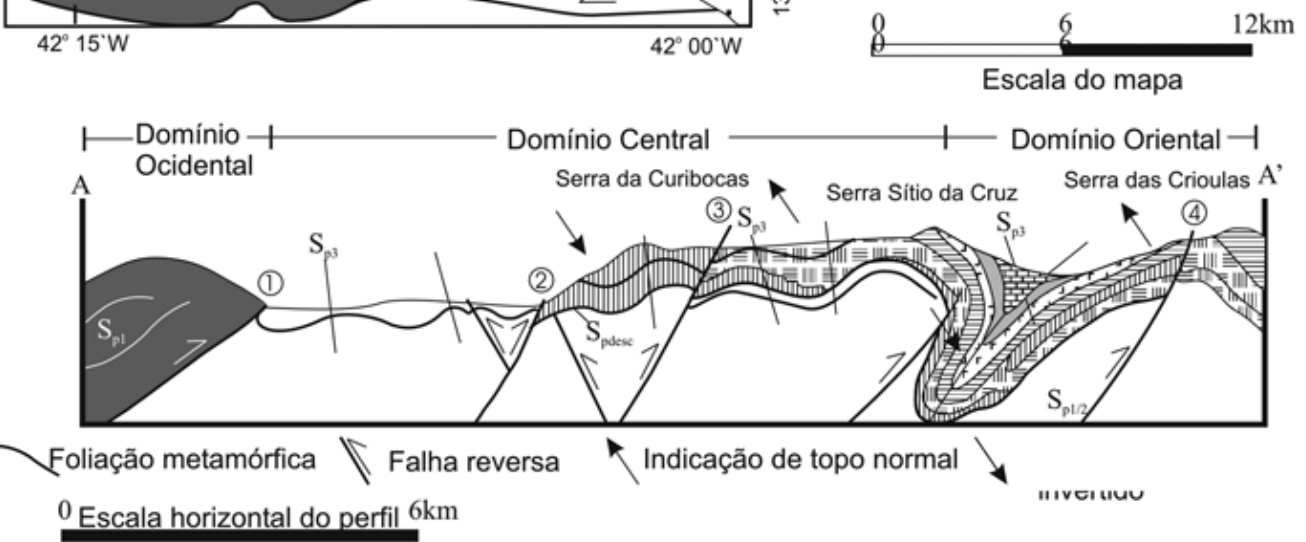

Zonas de cisalhamento: 1- São Timóteo, 2-Paramirim, 3-Serra da Curiboca, 4- Iguatemi, 5 Zona de transferência de Itanajé.

Figura 9 - Mapa e perfil geológico esquemático do Sinclinal de Água Quente, baseado em Barbosa \& Dominguez (1996). A escala vertical do perfil está ampliada 2 vezes.

ção Ouricuri do Ouro, as rochas metavulcânicas da Formação Rio dos Remédios e os diques de composição gabróica, intrusivos no Supergrupo Espinhaço. A estrutura deformacional mais proeminente é uma foliação milonítica de baixo ângulo, da etapa $\mathrm{D}_{\text {pdesc }}$, que afeta tanto o substrato, quanto às rochas das Formações Rio dos Remédios e Ouricuri do Ouro.

No embasamento, a foliação e a lineação de estiramento desenvolvidas nas zonas $\mathrm{D}_{\text {pdesc }}$ possuem orientação preferencial em 246/31 e 258/30 respectivamente (Figs. 11a, b). Na cobertura essas estruturas mostram orientações de 252/15 e 253/29, respectivamente (Figs. $11 \mathrm{c}, \mathrm{d})$. A foliação $\mathrm{S}_{\text {pdesc }}$ em ambos os casos, pode estar marcada pela clorita, epidoto, mica branca e biotita verde e a lineação de estiramento por filossilicatos e ribbons policristalinos de quartzo. Nas rochas vulcanoclásticas, fragmentos de rochas estirados são freqüentemente encontrados alinhados com essa estrutura. No interior das zonas de cisalhamento $\mathrm{D}_{\text {pdesc }}$, a deformação é heterogeneamente distribuída e porções intensamente deformadas, intercalam-se com porções pouco deformadas. Dessa forma, rochas protomiloníticas, miloníti- 



Figura 10 - Diagramas estereográficos sinópticos (hemisfério inferior) das estruturas deformacionais identificadas no domínio ocidental do Compartimento III..

cas e filoníticas intercalam-se com sigmóides de rocha metavulcânicas, metareníticas e metaconglomeráticas.

$\mathrm{O}$ embasamento está diretamente justaposto a metarenitos e metaconglomerados. Essas rochas, por sua vez, estão colocadas tectonicamente sobre as metavulcânicas da Formação Rio dos Remédios. Os contatos entre essas unidades são tectônicos e estão marcados por duas importantes zonas de cisalhamento reversas de alto ângulo, relacionadas com $\mathrm{D}_{\mathrm{p} 1} / \mathrm{D}_{\mathrm{p} 2}$. De oeste para leste, a primeira delas, a zona de cisalhamento de Paramirim, coloca o embasamento sobre os metarenitos e metaconglomerados da Formação Ouricuri do Ouro (Fig. 12) e também sobre as metavulcânicas da Formação Rio dos Remédios (vide perfil da Fig. 9). A outra, denominada de zona de cisalhamento Serra da Curiboca, coloca as rochas da Formação Ouricuri do Ouro sobre as unidades metavulcânicas da Formação Rio dos Remédios. Essas estruturas possuem orientação com máximos variando entre 241/58 e 259/59 (Fig. 11e), com lineação de estiramento de alta obliqüidade (Fig. 11f).

Apesar da intensa deformação observada nas rochas da cobertura do domínio central, nas regiões de menor deformação ainda é possível reconhecer feições sedimentares primárias, como estratificações cruzadas acanaladas e plano-paralelas de médio e grande porte. Nesse caso, o acamamento mergulha para oeste e a concavidade das estruturas sedimentares está voltada para leste. Essa relação sugere que na porção a oeste da Sinclinal de Água Quente, a estratigrafia está invertida. Isso implica que, nessa porção da Chapada Diamantina, um conjunto de metarenitos e metaconglomerados encontra-se sotoposto à Formação Rio dos Remédios.

No domínio central, a foliação $\mathrm{S}_{\text {pdesc }}$, o bandamento metamórfico a ela associada encontram-se dobrados e truncados pelas zonas de cisalhamento $\mathrm{D}_{\mathrm{p} 1} / \mathrm{D}_{\mathrm{p} 2}$. As dobras são abertas, com charneiras arredondadas, dispostas na direção 330/20 e vergentes para WSW. As- sociam-se a uma clivagem de crenulação que mergulha invariavelmente para ENE (060/78) (Fig. 11h). Associadas a essas dobras, zonas de cisalhamento estreitas (largura máxima de 1 metro) com movimentos antitéticos e dirigidos para ENE podem ser encontradas.

DOMÍNIO ORIENTAL Compreende parte da Sinclinal de Água Quente e engloba o conjunto de rochas terrígenas das formações Rio dos Remédios, Ouricuri do Ouro, Lagoa de Dentro e Açuruá, do Grupo Paraguaçu (Barbosa \& Dominguez 1996), bem como as rochas das formações Tombador e Caboclo, do Grupo Chapada Diamantina (Figs. 6c e 9). O limbo oeste da sinclinal mergulha em alto ângulo para WSW. Nele, predominam as dobras em todas as escalas de observação e as estruturas sedimentares, de uma maneira geral, estão bem preservadas. No interior das dobras, e no plano ortogonal ao transporte tectônico, superfícies de cisalhamento intra e interestratais e dobras de arrasto podem ser observadas. Na região da serra do Sítio da Cruz (Fig. 9), um trem de dobras desenvolve-se confinado à Formação Lagoa de Dentro e Tombador. Tais dobras variam desde abertas a apertadas e perdem expressão em direção ao topo das unidades. São assimétricas, apresentam pequena amplitude. Na Formação Tombador apresentam estilo chevron e são assimétricas, em $\mathrm{Z}$, com limbo normal e invertido mergulhando em baixo e médio a alto ângulo para WSW, respectivamente. Na serra Sítio da Cruz (Fig. 9), a vergência das dobras desenvolvidas naquela unidade é para ENE e a sua envoltória mergulha suavemente para esse quadrante. Á medida que se caminha para leste, ainda no limbo oeste da sinclinal, os ângulos de mergulho da superfície axial diminuem e os da envoltória das dobras assimétricas progressivamente aumentam. Localmente, verificase a inversão do sentido de mergulho (Fig. 13a). Nas unidades pelíticas da Formação Açuruá, desenvolve-se 


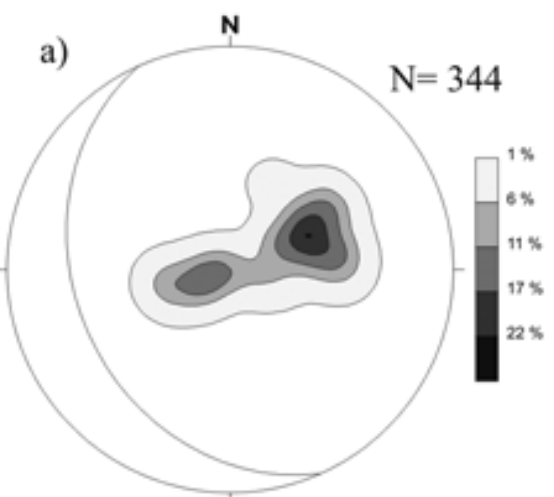

Foliação milonitica - $\mathrm{S}_{\text {pseve }}$ Embasamento

Compartimento III

Domínio central

Máximo: 246/31

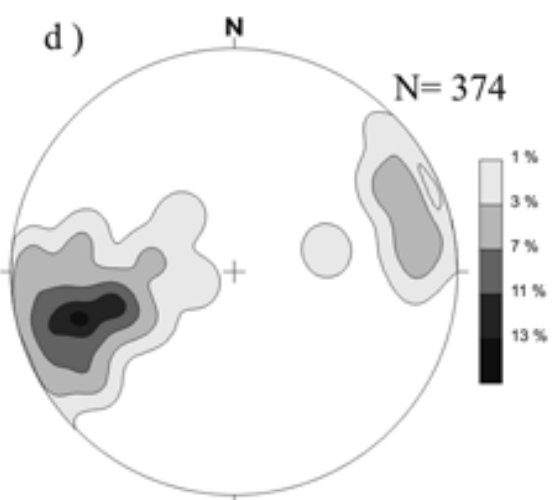

Lineação de estiramento $-L_{\text {pdeses }}$ Cobertura

Compartimento III Domínio central Máximo: 253/29

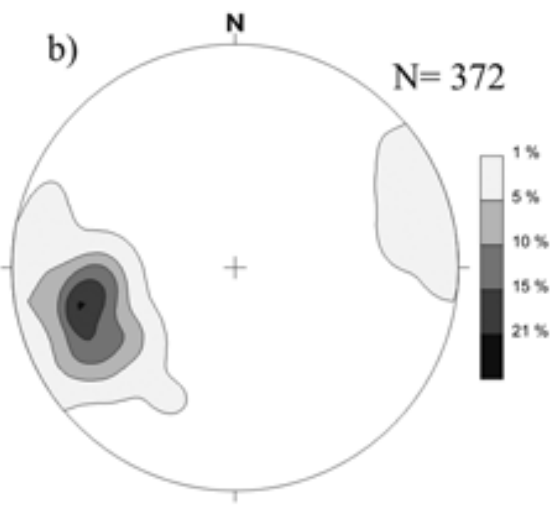

Lineação de estiramento - $L x_{\text {pdevo }}$ Embasamento Compartimento III Domínio central Máximo: 258/30

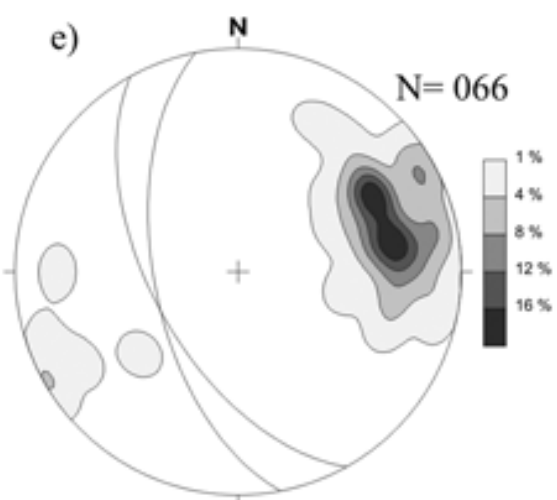

Foliação milonítica - $\mathrm{S}_{\mathrm{ptp2}}$ Embasamento e Cobertura Compartimento III Domínio central Máximos: 241/58 // 259/59

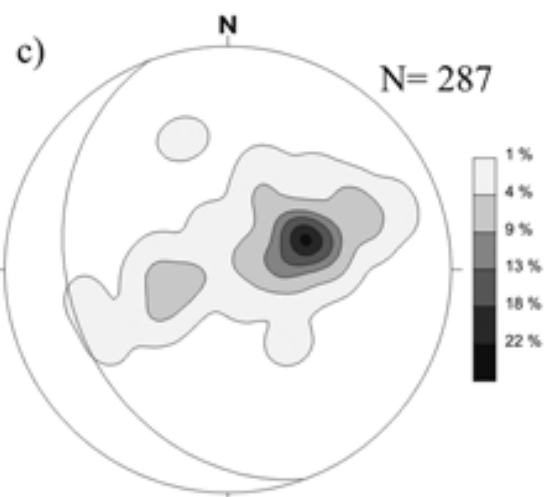

Foliação milonítica - $\mathrm{S}_{\text {pdesc }}$ Cobertura Compartimento III Domínio central Máximo: 252/15

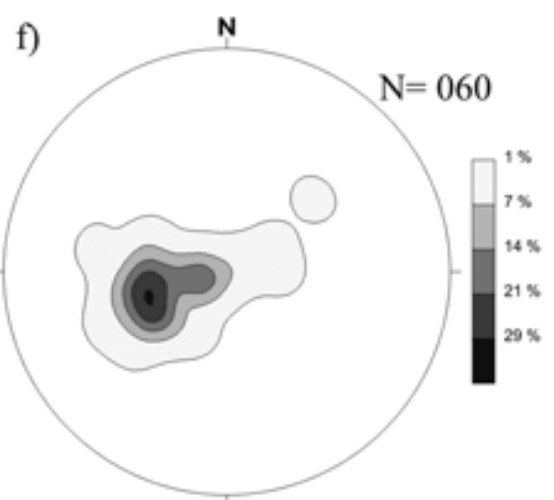

Lineação de estiramento - $L x_{\text {ptipp }}$ Embasamento e Cobertura Compartimento III Domínio central Máximo: 251/59

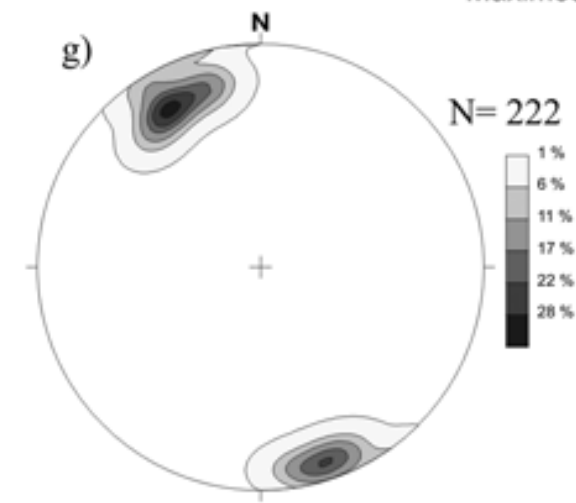

Lineação de Charneira de dobras - $\mathrm{Lb}_{0 \mathrm{p},}$ Embasamento e Cobertura Compartimento III Máximo: $330 / 20$



Foliação milonitica - $\mathrm{S}_{\mathrm{pa}}$ Embasamento e Cobertura Compartimento III - Domínio central Máximo: 060/78

Figura 11 - Diagramas estereográficos sinópticos (hemisfério inferior) das estruturas deformacionais identificadas no domínio central do Compartimento III..

uma proeminente clivagem plano axial, de natureza filítica, com orientação 245/51 (Fig. 14). Nos domínios de maior deformação, dobras intrafoliais envolvendo o acamadamento primário são transpostas por foliação milonítica $\mathrm{S}_{\text {pdesc }}$. Por outro lado, porções mais preservadas do acamamento podem também ser observadas nos domínios de menor deformação.

Na Formação Tombador, apesar do desenvolvimento de dobras, estruturas sedimentares ainda podem ser reconhecidas. Nos carbonatos e pelitos da Formação Caboclo, a deformação é acomodada por meio de falhas de empurrão articuladas a zonas de cisalhamento 


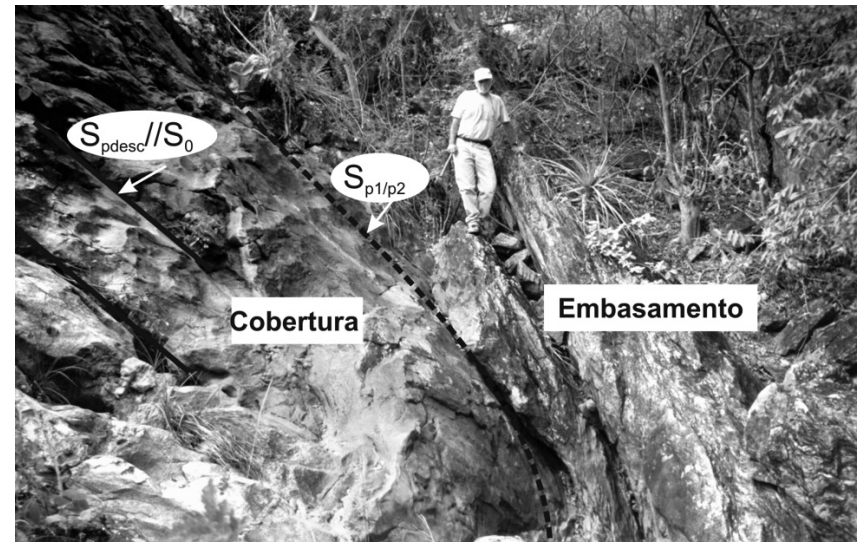

Figura 12 - Contato entre o embasamento e a cobertura sedimentar do Supergrupo Espinhaço na zona de cisalhamento Paramirim (Compartimento III, domínio central).

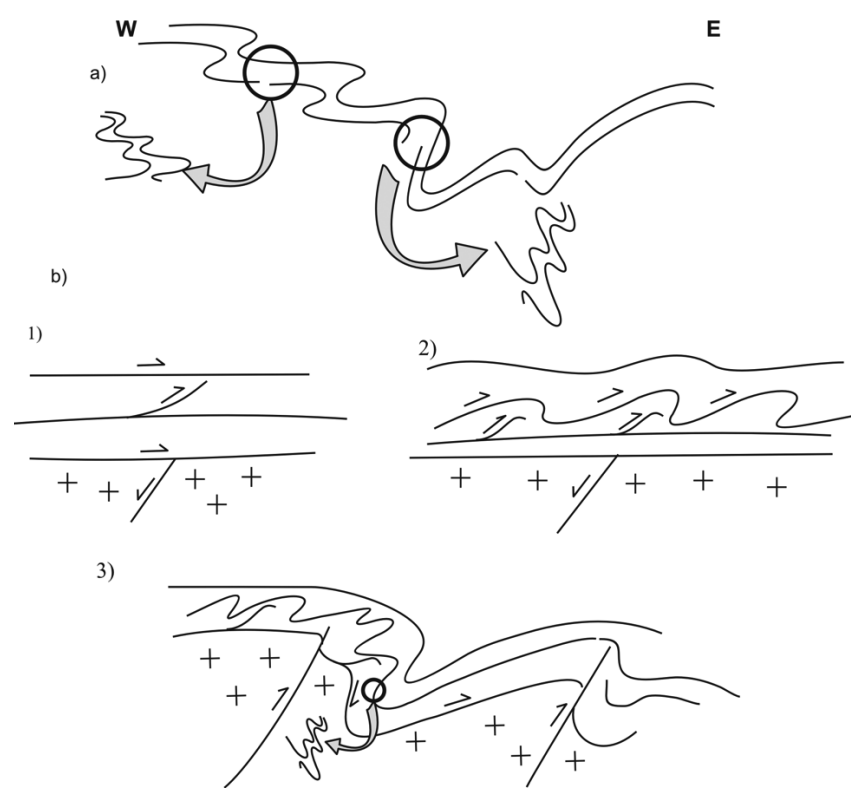

Figura 13 - Configuração esquemática das dobras anômalas associadas com a fase $D_{p 1} / D_{p 2}$ identificadas $m$ Modelo para a geração da estrutura mostrada em a: $\left.b_{1}\right)$ nucleação de zonas de cisalhamento de baixo ângulo; $b_{2}$ ) nucleação de dobras; $e_{3} b_{3}$ ) ativação de zonas de cisalhamento no embasamento e rotação dos elementos estruturais anteriormente nucleados.

intra-estratais, com orientação NNW/SSE e lineação WSW-ENE e por dobras de arrasto envolvendo o acamadamento primário parapelo à $\mathrm{S}_{\text {pdes }}$

Na região da serra das Crioulas (Fig. 9), desenvolvem-se dobras com geometria em kink. A superfície axial dessas dobras orienta-se, preferencialmente, segundo NNW/SSE e mergulha para WSW.

Na figura 15 está apresentado um modelo esquemático para explicar a geração da sinclinal de Água

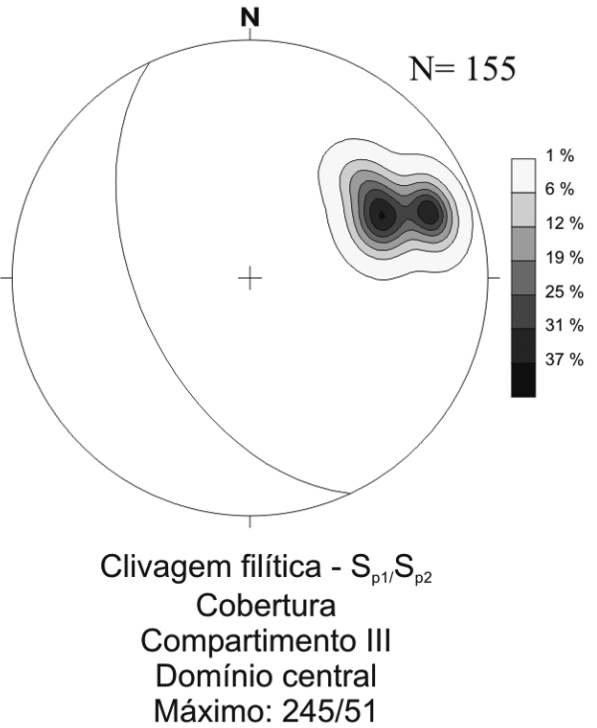

Figura 14 - Diagrama estereográfico sinóptico (hemisfério inferior) da foliação plano axial das dobras identificadas no domínio oriental do Compartimento III.

Quente, que envolve primeiramente a nucleação de falhas e dobras acima da interface embasamento/cobertura seguida por reativação de falhamentos ancorados no embasamento que rotacionam as estruturas anteriormente nucleadas.

\section{A INTERAÇÃO EMBASAMENTO/COBERTURA AO LONGO DA BORDA OCIDENTAL DA CHA-} PADA DIAMANTINA No bordo ocidental da Chapada Diamantina, as estruturas deformacionais marcam a fase de inversão frontal do Aulacógeno do Paramirim. A intensidade da deformação cresce de norte para sul, havendo o envolvimento do embasamento na deformação da cobertura. Ao norte do paralelo $12^{\circ} 45^{\prime} \mathrm{S}$, as unidades sedimentares repousam diretamente sobre o substrato e as relações primárias estão bem preservadas. No embasamento, as zonas de cisalhamento com movimentos normais, nucleadas no período de expansão do Aulacógeno do Paramirim permanecem praticamente intactas. À medida que se dirigem para sul, tais zonas são progressivamente reativadas e positivamente invertidas. Na região a sul do paralelo $13^{\circ} 00^{\prime} \mathrm{S}$ (Fig. 2), observa-se o clímax dessa inversão, com grandes falhas associadas a inversões estratigráficas das unidades do Supergrupo Espinhaço, entre as cidades de Rio do Pires e Paramirim.

A partir das relações de truncamento entre as estruturas observadas no embasamento e na cobertura sedimentar, foi possível estabelecer uma cronologia relativa de nucleação entre elas (Fig. 15). A deformação se inicia com o descolamento entre o substrato e a cobertura, associadas com a etapa $\mathrm{D}_{\text {pdesc }}$ (Fig. 15a). Durante essa etapa, zonas de cisalhamento inter e intra-estratais, com vergência para ENE foram nucleadas. Em seguida, 


embasameno cristalino e a cobertura

Figura 15 - Modelo para explicar a evolução tectônica da borda ocidental da Chapada Diamantina, na região compreendida entre as cidades de Rio do Pires e Itanajé. No compartimento I a história geológica se encerra na fase $D_{\text {pdesc }}$. No Compartimento II, nas fases $D_{p 1} / D_{p 2}$. A fase $D_{p 3}$ só é observada no Compartimento III.

dobras de grandes amplitudes foram geradas e deformam as estruturas preexistentes (Fig. 15b). Nas etapas seguintes, $\mathrm{D}_{\mathrm{p} 1} / \mathrm{D}_{\mathrm{p} 2}$, o encurtamento segundo WSW/ENE leva ao desenvolvimento de zonas de cisalhamento de alto ângulo enraizadas no embasamento (Fig. 15c) que estão bem expostas nos compartimentos II e III.

No estágio final de deformação, desenvolvemse dobras com vergência oposta ao do conjunto dominante, ou seja, para WSW (Fig. 15d). Tais estruturas foram apenas observadas no flanco ocidental da Sinclinal de Água Quente.

As estruturas compressionais que marcam a etapa de envolvimento do embasamento na deformação orientam-se na direção NNW/SSE e, em geral, são estruturas de alto ângulo, com valores de mergulho aci- ma dos $60^{\circ}$. De acordo com Sibson (1985), o ângulo máximo de mergulho para a nucleação de zonas de cisalhamento reversas é em torno de $30^{\circ}$. Falhas desse tipo, com mergulhos superiores aos previstos, sugerem reativação de estruturas antigas, que no caso da Chapada Diamantina poderia ser tanto a foliação gnáissica do embasamento, quanto as zonas normais da fase de instalação do aulacógeno. A reativação de estruturas com mergulhos elevados como falhas reversas pode estar relacionado com a presença de fluidos (Ivins et al. 1990, Yin \& Ranalli 1992, Sibson 1990) e com a posição das estruturas com relação à direção de máxima compressão (Sibson 1985, Etheridge 1986, Letouzey 1990, Coward 1994, Nguyen et al. 1998).

Ao adentrarem a cobertura, as zonas de cisalha- 
mento nucleadas no embasamento rotacionam as estruturas da fase dos descolamentos, gerando um arranjo do tipo dominó-invertido, que evolui para o desenvolvimento de culminações antiformais nucleadas pelo embasamento, como sugerido por Alkmim \& Danderfer Fo (1995). Na Sinclinal de Água Quente, as zonas de cisalhamento $\mathrm{D}_{\mathrm{p} 1} / \mathrm{D}_{\mathrm{p} 2}$ foram responsáveis pelas inversões estratigráficas, repetições de camadas, intercalações entre metassedimentos e embasamento e pelos padrões de dobras assimétricas em $\mathrm{Z}$ envolvendo as rochas da cobertura no limbo oeste da Sinclinal de Água Quente.

Apenas na Sinclinal de Água Quente, onde as inversões estratigráficas acontecem, as estruturas $D_{\text {}}$ $\mathrm{D}_{\mathrm{p} 1}$ e $\mathrm{D}_{\mathrm{p} 2}$ estão dobradas pelas estruturas da etapa $\mathrm{D}_{\mathrm{p} 3}$. Tais dobras podem estar associadas com a nucleação de retroempurrões nas fases finais de deformação, como sugerido por Danderfer Fo (1990). As zonas de cisalhamento $\mathrm{D}_{\mathrm{p} 3}$ poderiam ter aproveitado estruturas distensionais com mergulho para oeste e que poderiam ter sido reativadas devido à presença de algum anteparo que impediu o fluxo tectônico para leste e em função do grau de encurtamento já adquirido.

$\mathrm{O}$ metamorfismo sin-deformacional cresce de norte para sul acompanhando a crescente intensidade de deformação, atingindo, possivelmente, temperaturas máximas entre 400 e $520^{\circ} \mathrm{C}$.

DISCUSSÃO Como demonstrado nas seções anteriores, de norte para sul, ao longo do bordo ocidental da Chapada Diamantina, as estruturas deformacionais do embasamento, do Complexo Lagoa Real e da cobertura revelaram um aumento progressivo da deformação e do metamorfismo nesse sentido. Esses dados estão de acordo com aqueles apresentados por Danderfer Fo (1990) e Danderfer Fo (2000). Do lado oeste do Corredor do Paramirim, na serra do Espinhaço Setentrional, Danderfer Fo (2000) observou um comportamento semelhante, que também fora detectado por Moutinho da Costa \& Inda (1982). Na porção do Espinhaço Setentrional situada ao norte do paralelo $12^{\circ} 45^{\prime} \mathrm{S}$, de acordo com aqueles autores, o contato oeste entre as unidades do Supergrupo Espinhaço e o embasamento é discordante e estaria na posição original. Em direção ao sul, a superfície de contato passa gradativamente a ser ativada pelo alojamento de zonas de cisalhamento reversas. Já ao sul do paralelo $12^{\circ} 45^{\prime} \mathrm{S}$, inversões estratigráficas são reconhecidas. Da mesma forma que a deformação, o grau metamórfico cresce de norte para sul.

Os resultados obtidos por Moutinho da Costa \& Inda (1982) e Danderfer Fo $(1990,2000)$, somados com os aqui apresentados, sugerem que a inversão do Aulacógeno do Paramirim foi parcial e está limitada ao norte na altura do paralelo $12^{\circ} 45^{\prime} \mathrm{S}$, nas imediações das cidades de Boquira e Ibiajara.

As estruturas deformacionais reconhecidas no bordo ocidental da Chapada Diamantina foram nucleadas tanto nas rochas do embasamento quanto naquelas do Grupo Paraguaçu e das formações Caboclo e Tombador (Grupo Chapada Diamantina). Por outro lado, no extremo meridional da Chapada Diamantina, a sul da área estudada, as estruturas das etapas $\mathrm{D}_{\mathrm{p} 1} / \mathrm{D}_{\mathrm{p} 2}$ truncam as estruturas da zona de cisalhamento Brumado-Caetité, gerada em uma fase precoce do processo de inversão (Cruz \& Alkmim 2006) e essa, por sua vez, corta as rochas da Formação Salitre (Grupo Una, Supergrupo São Francisco). As rochas Salitre têm idade máxima de cerca de $750 \mathrm{Ma}$, de acordo com os dados obtidos por Macedo \& Bonhomme (1984), Misi \& Veizer (1996) e Toulkeridis et al. (1999). Dessa forma, a idade máxima da fase $\mathrm{D}_{\mathrm{p}}$ fica em $750 \mathrm{Ma}$, correspondendo, muito provavelmente, a uma manifestação do evento Brasiliano ao final do Neoproterozóico.

Estruturas deformacionais envolvendo a interação embasamento/cobertura vêm sendo bastante estudadas por alguns autores (por exemplo, McConnel 1994 e Mitra \& Mount 1998). Tais trabalhos, entretanto, tiveram como principal foco a geometria e mecanismos de deformação da cobertura, não dando ênfase à caracterização nem à definição das estruturas deformacionais nucleadas no substrato cristalino. Além disso, nesses trabalhos não é clara nem a relação temporal entre as estruturas nucleadas no embasamento e na cobertura e nem o papel desempenhado pelas estruturas pretéritas do embasamento na acomodação da deformação na cobertura durante a interação entre essas duas unidades estratigráficas. Os modelos sugeridos pelos autores citados acima se referem às variações na geometria das dobras nucleadas na cobertura sedimentar e aos mecanismos envolvidos na sua geração. É consenso entre esses autores que o desenvolvimento das dobras nas unidades sedimentares envolve processos de deslizamento flexural e de nucleação de zonas de falhas sem, contudo, estabelecer uma cronologia relativa para a nucleação dessas duas estruturas.

A Chapada Diamantina apresenta ótimas exposições de rochas metassedimentares e de elementos estruturais de todas as fases de inversão do Aulacógeno do Paramirim identificadas por Cruz \& Alkmim (2006), sendo, portanto, um local ideal para a busca das respostas a problemas levados a cerca da cronologia relativa entre as estruturas sin-inversão nucleadas no embasamento e na cobertura. A deformação inicia-se com o descolamento entre o embasamento e a cobertura e nucleação de zonas de cisalhamento intra e interestratais. Com o avanço da deformação é que o embasamento é envolvido, rotacionando estruturas anteriormente nucleadas e provocando assimetrias anômalas.

Enquanto em cinturões orogênicos a deformação é amplamente desenvolvida, em regiões cratônicas ela tende a ser concentrada em zonas específicas que experimentam uma longa história de deformação. A propagação da deformação a partir de cinturões dobrados em direção às áreas cratônicas pode levar à reativação e a inversão de antigas estruturas e esses processos podem se estender por grandes áreas (Nelson 1991, Howell \& van der Pluijm 1990, Marshak 2004). Durante a inversão frontal do Aulacógeno do Paramirim, a ativação do embasamento reflete processos de reativação tectônica. Nesse contexto, zonas de cisalhamento foram desenvolvidas aproveitando antigas estruturas do 
embasamento.

CONCLUSÕES A partir das informações obtidas, pode ser concluído que:

1. No extremo ocidental da Chapada Diamantina podem ser observadas estruturas relativas à fase de inversão frontal do Aulacógeno do Paramirim. De acordo com as relações de truncamento encontradas, essa fase pode ser dividida em três etapas. A primeira, $\mathrm{D}_{\text {pdesc }}$, associa-se com os descolamentos entre as unidades da cobertura e do embasamento. As duas seguintes, $\mathrm{D}_{\mathrm{pl}} /$ $\mathrm{D}_{\mathrm{p} 2}$, marcam a fase de envolvimento do embasamento na deformação da cobertura. Todas essas etapas possuem vergência para ENE. A quarta e última etapa de deformação, $\mathrm{D}_{\mathrm{p} 3}$, nucleia um conjunto de estruturas antitéticas, com vergência para WSW.

2. No bordo ocidental da Chapada Diamantina, independente da etapa de deformação considerada, quando comparadas às estruturas nucleadas no embasamento e na cobertura sedimentar, observa-se uma forte semelhança entre elas. O sistema como um todo responde por meio do desenvolvimento de zonas de cisalhamento que se dispõem em alto ângulo em relação ao campo de compressão máxima e vergentes para ENE. Tanto no embasamento quanto na cobertura, os movimentos são invariavelmente frontais, com deformação e metamorfismo crescendo para sul. Em direção a leste, a deformação e metamorfismo também diminuem, assim como o envolvimento do embasamento na deformação da cobertura.

3. Fatores como a geometria da bacia, orientação das estruturas pré-inversão e espessura de sedi- mentos devem ter controlado a geometria das estruturas nucleadas no embasamento e na cobertura, favorecendo a semelhança entre elas.

4. Ao longo da borda oeste da Chapada Diamantina, a deformação cresce de norte para sul e de leste para oeste, acompanhado de crescimento de metamorfismo nesse mesmo sentido. Na região ao sul da cidade de Rio do Pires a deformação é máxima e inversões estratigráficas estão presentes.

5. A estruturação estudada remonta ao Neoproterozóico e marca a presença do Ciclo Brasiliano na região, tanto no embasamento quanto na cobertura. Dessa forma, sugere-se que o contato sudeste tradicional do Cráton do São Francisco proposto por Almeida (1977) seja revisto.

Agradecimentos Os autores gostariam de expressar seus agradecimentos à Companhia Baiana de Pesquisa Mineral (CBPM), à Industrias Nucleares do Brasil (INB), à UFOP, à UFBA e à Companhia de Pesquisa de Recursos Minerais (CPRM-SUREG-Salvador) pelo apoio durante a realização desta pesquisa. Além disso, os autores agradecem aos revisores anônimos. S.C.P. Cruz foi contemplada pelo CNPq com uma bolsa durante o programa de Doutorado (Processo no 140739/2000-9) e de Pós-Doutorado Júnior (Processo no 150127/2005-7). Além disso, foi contemplada com Bolsa de Pós-Doutorado 1 da FAPESB (Termo de Outorga 2083/2006) e pelo Projeto Universal do CNPq (Processo 475092/2004-0). F.F.Alkmim recebe auxílio do CNPq na forma de bolsa de produtividade em pesquisa (Processo no 300833/99-7).

\section{Referências}

Alkmim F.F. \& Danderfer Fo.A. 1995. Duas fases da evolução dos cinturões de dobramentos e empurrões e sua expressão na Faixa Araçuaí (MG) e na Chapada Diamantina (BA). In: SBG, Simpósio Nacional de Estudos Tectônicos, 5, Boletim de Resumos Expandidos, p. 1-2.

Alkmim F.F., Brito Neves B.B. \& Alves J.A. C. 1993. Arcabouço tectônico do Cráton do São Francisco - uma revisão. In: J.M. Dominguez, \& A. Misi (eds.) O Cráton do São Francisco. Reunião Preparatória do II Simpósio sobre o Cráton do São Francisco. Salvador, SBG/ Núcleo BA/SE/SGM/CNPq, p. 45-62.

Alkmim F.F., Chemale Jr.F. \& Endo I. 1996. A deformação das coberturas proterozóicas do Cráton do São Francisco e o seu significado tectônico. Rev. Esc. Minas, 49:22-38.

Almeida F.F. 1977. O Cráton do São Francisco. Rev. Bras. Geoc., 4:349-364.

Babinski M., Brito-Neves B.B., Machado N., Noce C.M., Ulhein A. \& Van Schumus W.R. 1994. Problemas na metodologia $\mathrm{U} / \mathrm{Pb}$ em zircões de vulcânicas continentais: o caso do Grupo Rio dos Remédios, Supergrupo Espinhaço, no estado da Bahia. In: SBG, Congresso Brasileiro de Geologia, 2, Boletim de Resumos Expandidos, p. 409410.

Barbosa J.S.F \& Dominguez J.M.L. (Eds.) 1996. Mapa Ge- ológico do Estado da Bahia. Escala: 1.000.000. Texto explicativo, Salvador, $382 \mathrm{p}$.

Bastos-Leal L.R. 1998. Geocronologia U/Pb (Shrimp), ${ }^{207} \mathrm{~Pb} /{ }^{206} \mathrm{~Pb}, \mathrm{Rb}-\mathrm{Sr}$, Sm-Nd e $\mathrm{K}-\mathrm{Ar}$ dos Terrenos GranitoGreenstone do Bloco do Gavião: Implicações para Evolução arquena e proterozóica do Cráton do São Francisco, Brasil. Tese de Doutorado, Instituto de Geociências, Universidade Estado de São Paulo, 178 p.

Bento R.V. 2001. Análise estrutural das relações de contato entre as litologias do Vale do Paramirim e da borda oeste da Chapada Diamantina, SW do Estado da Bahia. In: SBG/BA-SE, Simpósio Nacional de Estudos Tectônicos, 7, Anais, p. 135-138.

Brito-Neves B.B., Cordani U.G. \& Torquato J.R. 1980. Evolução geocronológica do Precambriano no estado da Bahia. In: Inda H.A.D. \& Duarte F.B. Geologia e Recursos Minerais do Estado da Bahia, 3, SME-COM, p. 1-101.

Cordani U.G., Sato K. \& Marinho M.M. 1985. The geologic evolution of the ancient granite-greenstone terrane of central-southern Bahia Brazil. Precambrian Res., 27:187213.

Cordani U.G., Iyer S.S., Taylor P.N., Kawashita K., Sato K. \& Mcreath I. 1992. Pb-Pb, Rb-Sr, and K-Ar sistematic of the Lagoa Real uranium province (south-central Bahia, 
Brazil) and the Espinhaço Cycle (ca. 1.5-1.0 Ga). ). J. South Am. Earth Sci., 5:33-46.

Costa P.H.O., Andrade A.R.F., Lopes G.A.C. \& Souza S.L. 1985. Projeto Lagoa Real - Mapeamento Geológico 1:25.000. CBPM/NUCLEBRAS/SME, volume 1, 455 p.

Coward M. 1994. Inversion Tectonics. In: P.L. Hancock (ed.) Continental Deformation, Oxford, England, p. 289-304.

Cruz S.C.P. 2000. Zonas de cisalhamento no núcleo do anticlinal de Gouveia (MG): Processos Deformacionais e Metamórficos. Dissertação de Mestrado, Departamento de Geologia, Universidade Federal de Ouro Preto, 279 p.

Cruz S.C.P., Martins V.B., Santana O.S, Almeida J.S., Dias V.M. \& Martins C.F.N. 1998. Geologia e Evolução tectônica do braquissinclinal de Água Quente, Chapada Diamantina Ocidental, Bahia, Brasil. In: SBG/NMG, Congresso Brasileiro de Geologia, 40, p. 404.

Cruz S.C.P. \& Alkmim F.F. 2006. The tectonic interaction between the Paramirim Aulacogen and the Araçuaí Belt, São Francisco Craton region, Easter Brazil. Academia Brasileira de Ciências (no prelo).

Danderfer Fo.A. 1990. Análise estrutural descritiva e cinemática do Supergrupo Espinhaço na região da Chapada Diamantina (BA). Dissertação de Mestrado, Departamento de Geologia, Univ. Federal de Ouro Preto, 99 p.

Danderfer Fo.A., Lagoeiro L.E. \& Alkmim F.F. 1993. O sistema de dobramentos e empurrões da Chapada Diamantina (BA): registro da inversão do Aulacógeno do Espinhaço no decorrer do Evento Brasiliano. In: SBG, Simpósio sobre o Cráton do São Francisco, 2, Anais, p. 197-199.

Danderfer $\mathrm{F}^{\circ}$.A. 2000. Geologia sedimentar e evolução tectônica do Espinhaço Setentrional, estado da Bahia. Tese de Doutoramento, Instituto de Geociências, Universidade Federal de Brasília, 497 p.

Etheridge M.A. 1986. On the reactivation of extensional fault systems. Phil. Trans. Royal Soc. Edinburgh, 71:69-96.

Guimarães J.T. 1996. A Formação Bebedouro no estado da Bahia: Faciologia, Estratigrafia e Ambiente de Sedimentação. Dissertação de Mestrado, Instituto de Geociências, Universidade Federal da Bahia, 155 p.

Howell P.D. \& van der Pluiijm B.A. 1990. Early history of the Michigan basin: subsidence and Apalachian tectonics. Geology, 18:1195-1198.

Ivins E.R., Dixon T.H. \& Golombek M.P. 1990. Extensional reactivation of an abandoned thrust: a bound on shallowing in the brittle regime. J. Struct. Geol., 12:303314.

Jardim-de-Sá E.F., Bartels R.L., Brito-Neves B.B. \& McReath I. 1976. Geocronologia e o modelo tectonomagmático da Chapada Diamantina e do Espinhaço Setentrional, Bahia. In: SBG, Congr. Bras. Geologia, 29, Anais, p. 205-227.

Letouzey J. 1990. Fault reactivation, inversion and fold-thrust belt. In: J. Letouzey (ed.) Petroleum and Tectonic Mobile Belts. Editions Technip, Paris, p. 101-128.

Macedo M.H. \& Bonhome M.G. 1984. Contribuição a cronoestratigrafia das Formações Caboclo, Bebedouro e Salitre na Chapada Diamantina (BA) pelos métodos RB-Sr e K-Ar. Rev. Bras. Geoc., 14:153-163.

Marshak S. 2004. Phanerozoic tectonics of the United States Midcontinent. In: B.A. van der Pluijm \& S. Marshak (eds.) Earth Structure, Norton \& Company, United State of America, 2 ed., 646 p.

Maruèjol P., Cuney M., Fuzikawa Maria Netto \& A. Poty, B. 1987. The Lagoa Real Subalkaline Granitic Complex (South Bahia, Brazil): A Source for Uraniun Mineralizations Associated With Na-Ca Metassomatism. Rev. Bras. Geoc., 4:578-594.

McConnell D.A. 1994. Fixed-hinge, basement-involved faultpropagation folds, Wyoming. Geol. Soc. Amer. Bull., 106:1583-1593.

Mcdowell R.J. 1997. Evidence for synchronous thin-skinned and basement deformation in the Cordilleran fold-thrust belt: the Tendoy Mountais, Southwestern Montana. J. Struct. Geol., 1:77-87.

Misi A. \& Veizer J. 1996. Chemostratigraphy of neoproterozoic carbonate sequences of the Una Group, Irecê Basin, Brazil. In: SBG/NBA-SE, Congresso Brasileiro de Geologia, 39, Anais., v.5, p. 487-489.

Mitra S. \& Mount S. 1998. Foreland basement-involved structures. AAPG Bull., 1:70-109.

Moutinho da Costa L.A. \& Inda H.A. V. 1982. O Aulacógeno do Espinhaço. Ciências da Terra, 2:13-18.

Nelson W.J. 1991. Structural styles of the Illinois basin. In: M.W. Leighton (ed.) Interior cratonic basin. American Association of Petroleum Geologist Memoir, 51, p. 209243.

Nguyen P.T., Cox S.F., Harris L.B. \& Powell C.M. 1998. Fautl-calve behaviour in optimally oriented shear zones: an example at the revenge Gold mine, Kambalda, western Australia. J. Struct. Geol., 12:1625-1640.

O’Dea M.G. \& Lister G.S. 1995. The role of ductility contrast and basement architecture in the structural evolution of Crystal Creek block, Mount Isa Inlier, NW Queensland, Australia. J. Struct. Geol., 7:949-960.

Pedrosa-Soares A.C., Noce C.M., Wiedemann C.M. \& Pinto C.P. 2001. The Araçuaí-West-Congo Orogen in Brazil: an overview of a confined orogen formed during Gondwanaland assembly. Precambrian Res., 1-4:307-323.

Schobbenhaus C., Campos D.A., Derze G.R. \& Asmus H.E. 1981. Mapa Geológico do Brasil e da Área Oceânica Adjacente, Incluindo Depósitos Minerais. Brasília, DNPM, escala 1:2.500.000.

Sibson R.H. 1985. A note on fault reactivation. J. Struct. Geol., 7:751-754.

Sibson R.H. 1990. Faulting and fluid flow. MAC Short Course on Crustal Fluids Handbook, 18:94-131.

Toulkeridis T., Babinski M., Buchwaldt R., Brito Neves B.B., Todt W. \& Santos R. 1999. Are varangian or sturtian the glacial deposits on the São Francisco Cráton? Evidence from determination of sedimentary rocks and minerals of the Neoproterozoic Una Group. In: South American Symposium on Isotope Geology, 2, Cordoba, Anais, p. 453-456.

Yin Z.M. \& Ranalli G. 1992. Critical stress difference, fault orientation and slip direction in anisotropic rocks under non-Andersonian stress systems. J. Struct. Geol., 14:237244.

Manuscrito CSF-1667

Submetido em 31 de maio de 2006 Aceito em 01 de março de 2007 